\title{
Effects of Cooperative Learning on Achievement Motivation of Female University Students
}

\author{
Min Wang ${ }^{1}$ \\ ${ }^{1}$ Department of Physical Education, Shanghai University of Finance \& Economics, Shanghai, China \\ Correspondence: Min Wang, Department of Physical Education, Shanghai University of Finance \& Economics, \\ Guoding Road NO 777, Yangpu District, Shanghai, China. Email: yhc-wm@hotmail.com
}

Received: August 28, $2012 \quad$ Accepted: September 11, $2012 \quad$ Online Published: November 30, 2012
doi:10.5539/ass.v8n15p108
URL: http://dx.doi.org/10.5539/ass.v8n15p108

\begin{abstract}
This study aims to: 1) describe the effects of cooperative learning (CL ) on achievement motivation of female college students, and 2) compare the difference in the achievement motivation between the female college students learning through cooperative learning and those learning through the traditional learning pattern. In this study, an intervention program was devised as part of a new learning style to encourage the performance of physical education and achievement motivation in which students (mean age $=21.2$ years, $\mathrm{N}=67$ ) were invited to participate as part of physical classes. The questionnaire were completed as pre-test at the beginning of the intervention for overall the treated and control groups and as post-tests at the end of week twelve. $T$ test measures were used to examine whether there were significant differences of achievement motivation within the two groups. The results showed that the cooperative learning classes to improve the achievement motivation among the female college students.
\end{abstract}

Keywords: cooperative learning, female university students, motivation

\section{Introduction}

Since 1985, China's economic system has been transitioning from a planned economy to a market one. China's political system has begun to improve from the centralization of state power to local democracy and autonomous diversification. These changes in China's economic and political systems have provided a suitable environment for educational reforms, shifting from a traditionally rigid and closed system to a flexible and more open one (Guan \& Meng, 2007). Influenced by innovation, the National PE curriculum has undergone major changes as well. In 2002, a new curricular concept for PE was adopted and implemented. The Chinese Ministry of Education (2002) officially initiated the Course Standard of PE and Health, which outlines the general direction and aim for PE reform in the next decade. This course standard suggests that the focus of PE should evolve from its sport skill-related objectives to a fitness, health, cognitive, and affective orientation. In this new concept, the PE curriculum aims to develop motor competencies and promote healthy and safe lifestyles, sports participation, and social adaptability of students (Chinese Ministry of Education, 2002).

To achieve the goals of the new PE curriculum, schools were advised to shift PE teaching from direct teaching that focuses on the mastery of techniques to a facilitative style of teaching that emphasizes student interests and needs (Chinese Ministry of Education, 2002). Based on these guiding principles, various new pedagogical models have been introduced in the primary and secondary schools in China (Wang, Qiu, \& Xiao, 2010).

As a student-centered and inquiry-based pedagogical model, cooperative learning (CL) was introduced in China in the 1990s. At present, CL is provided as part of a pedagogy course and a pedagogical model for pre-service teachers in several universities. Furthermore, several workshops on CL are provided to in-service teachers from various cities of China. However, no studies on the effects of CL on students' achievement motivation in China have been conducted.

\subsection{Traditional Teaching}

The traditional teaching model was influenced by Kairov's pedagogy (1956) in Soviet Union (Wang, 2004). This teaching method begins with the instruction of the teacher, then practice of students (Jiang, 2007). Teacher's behavior occupies a dominant position in the whole learning process, which can not provide students with a chance to active learning and less opportunity to communicate with other students. In addition, physical educator 
may use inappropriate teaching practices which can lead to students stand. Monotonous teaching pattern and boring teaching content not only restricted a variety of teaching around waiting (Dunn, et al. 1991), "Waiting" students rarely experience the joy of involvement in activities patterns' developing but also make student lose their interesting for P.E. curriculum (Hao, et al. 2010) which can provide them a sense of worth, belonging, accomplishment, and priding.

\subsection{Cooperative Learning}

Cooperative Learning (CL) is an instructional model that also shifts the focus of learning to the student (Dyson, Griffin \& Hastie, 2004). A primary goal in CL is that each student becomes a heterogeneous groups to master the content. The students are not only responsible for learning the material, but also for helping their group-mates learn (Antil, Jenkins, Wayne, \& Vadasay, 1998; Putnam, 1998)

There is a growing body of research in education that reports the benefits of cooperative learning (Cohen,1994; Johnson \& Johnson, 1989; Kagan, 1990; Slavin, 1990,1996). Substantial evidence exists to support the idea that students working in small cooperative groups can master material presented by the teacher better than students working on their own (Cohen, 1994; Johnson \& Johnson, 1989; Slavin, 1990, 1996). CL also has social outcomes such as positive inter-group relations, the ability to work collaboratively with others, and the development of self-esteem (Cohen, 1994; Johnson \& Johnson, 1989; Slavin, 1990, 1996).

There are four major CL approaches: (a) conceptual, (b) structural, (c) curricular, and (d) complex instruction. First, Johnson and Johnson (1989) have developed the conceptual approach, which is based on the premise that teachers can learn the key elements of structuring effective cooperative learning activities. Johnson, Johnson, and Johnson-Holubec (1998) presented five main elements that they believe are necessary for cooperative learning to be successful. First, positive interdenpendence refers to each group member learning to depend on the rest of the group while working together to complete the task. Second individual accountability is defined as practices teachers use to establish and maintain student responsibility for appropriate behavior, engagement, and outcomes. Third, promotive face-to-face interaction is literally head-to head discussion around the group in close proximity to each other. Fourth, interpersonal and small group skills are developed through the tasks and include listening, shared decision making taking responsibility, learning to give and receive feedback, and learning to encourage each other. Finally, group processing refers to time allocated to discussing how well the group members achieved their goals and maintained effective working relationships.

One of the most appealing attributes of cooperative learning is its dual focus on social and academic outcomes (Antil et al., 1998; Cohen, 1994; Putnam, 1998). Research has shown that CL can have a positive impact on social variables including inter-group relations, ability to work collaboratively with others, and self-esteem (Jognson \& Johnson, 1989; Sapon-Shevin, 1994; Slavin, 1996).

Cooperative learning works to place the students at the center of learning. In a cooperative learning lesson, all students contribute to group work, and students rely on each other to complete the task. The teacher acts as a facilitator and works to shift the responsibility to the students while holding them accountable. Putnam (1998) point out that educators are not typically aware of the conditions that are essential for cooperative learning to lead to positive outcomes. Putnam (1998) suggested that "simply placing students in groups and asking them to cooperate will not ensure higher achievement or positive interpersonal outcomes" (p.18). The implementation of cooperative learning is a complex process (Antil et al., 1998; Cohen, 1994; Cohen \& Lotan, 1997; Dyson, 2002; Putnam, 1998) and it may take three or more years for a teacher to feel comfortable with this instructional model (Dyson, Griffin \& Hastie; 2004).

In physical education, CL has enhanced students' goals for lessons, helped students take responsibility through roles, improves students' motor skills and strategizing, enhanced students' communication skills, improves students' working together and help students accountable through the use peer assessment and task sheets (Dyson, 2001, 2002). Barrett (2000) found that cooperative structures increased students' trials in sports skills units. In addition, low- skilled male and female students also showed improved performances.

\subsection{Achievement Motivation}

Achievement Motivation was proposed by Atkinson and Feather (1966). They stated "the strength of motivation to perform some act is assumed to be a multiplicative function of the strength of the motive, the expectancy (subjective probability)that the act will have as a consequence the attainment of an incentive, and the value of the incentive: Motivation $=\mathrm{f}$ (Motive $\times$ Expectancy $\times$ Incentive)". Atkinson \& Feather (1966) also stated that a person's achievement oriented behavior is based on three parts: the first part being the individual's 
predisposition to achievement, the second part being the probability of success, and third, the individual's perception of value of the task.

Motivation, as it relates to students, is very important. The training literature has reported to exhibit a positive relationship with learning outcomes (Colquitt \& Simmering, 1998; Mathieu et al., 1992; Quinones, 1995). According to Keefe \& Jenkins (1993), students who have high motivation to achieve generally do well academically, and students with low motivation do not well do well academically (Keefe, Jenkins, 1993).

\section{Purpose:}

The first purpose is to examine the effect of cooperative learning on student achievement motivation.

The second purpose of this experimental study is to investigate the effects of two different teaching methods on achievement motivation of female college students in Shanghai, China.

\section{Research Method}

\subsection{Research Design}

Two groups of students participated in this study including one control (Teacher-centered techniques) group and one experimental group. A pre-test/post-test research design was followed to investigate the effects of an intervention program using CLS on the achievement motivation of female university students.

\subsection{Participants}

The comparative research design was adopt by collecting data from three college students cohorts. A total of 67 $2^{\text {nd }}$ year female students at Shanghai University of Finance and Economics who attended aerobics course responded to this survey. The subjects were 20-22 years old and were composed of 2 cohorts: (1) The first group $(\mathrm{N}=33)$ was used $\mathrm{CL}$ method (2) The second group $(\mathrm{N}=34)$ was applied the traditional teaching method.

\subsection{Intervention Program}

The 12-week teaching program, in which a series of aerobics movement examined and approved by Chinese Aerobic Association was taught by an expert on aerobics. The total of the 67 participants were selected randomly from the population. This technique was employed in order to achieve an unbiased selection of subjects (Ary, Jacobs \& Razavieh, 1990). The intervention program was sent to a supervisory committee and also experts in the field in China for checking the content of the plans. Most of the plans were amended to fit with the purpose of the study.

\section{Teachers Uses:}

The two teachers aged from 33 to 35 bachelor degree in physical education and sport science (Bachelor), and had six years of teaching experiences. Therefore, the teacher of the experimental group were exposed to a two-week training course on the implementation of the CLS technique (Goudas \& Magotsiou, 2009). The person who undertook the training of the teacher held a PhD. Degree in CL.

The cooperative learning training course included three main stages such as the theoretical cooperative learning approach, practical implemental and the control group. The subjects in two groups were exposed to achievement motivation test. The pretest scores helped to determine the prevailing level of the achievement motivation and the motor skills of the students.

After week twelve of the study, both groups were subjected to the post-test which was administrated the same procedure as the pre-test.

\subsection{Instruments}

The Achievement Motive Scale ( AMS) was adopted in this study. AMS (Gjesme, Nygard, 1970) was revised by Ye and Hagtvei K.A in 1998. This scale has 30 items, including the motivation of pursuing success (Ms) and motive to avoid failure (Mf). Responses were coded on a five-point scale (from not at all $=1$, to very much $=5$ ). The individual's perception of probability for achieving the task would cause a need to achieve and a fear of failure. Both are strong emotions that influence the individual's decision on whether or not to attempt the task (Bar-Tal, Frieze, and Greenberg, 1974). If a task simultaneously arouses an individual's motivation to approach the task and motivation to avoid the task, then the sum of the two motivations will be the result. If the result is more positive to approach the task, then the individual will be motivated toward the task. If the result is more positive to avoid the task, then the individual will be motivated to avoid the task (Atkinson, Feather, 1966). AMS has been translated in to many languages (Yeo, Lay See. 2012) and widely used in many fields (Xu, 2012; Chen, 2012; Che, 2004).The scale's split-half reliability is 0.77 and validity is 0.58 , coefficient of internal consistency is 0.68 . 


\subsection{Data Analysis}

The computer statistical program SPSS 18.0 package (PASW) was used to analyze quantitative data. Means were calculated for the experimental and control group based on the responses of the subjects to the AMS. The Paired-Samples $\mathrm{T}$ test was adopted to examine the difference of student achievement motivation between preand post- CL program. The Independent-Samples T test was applied to compare the effects of the traditional teaching and CL on student achievement motivation.

\section{Results}

Table 1. Independent-samples $t$ test of achievement between CL group and control group at post test

\begin{tabular}{cccccc}
\hline \multirow{2}{*}{ Achievement motivation } & \multicolumn{2}{c}{ GL group(N=33) } & \multicolumn{2}{c}{ Control group(N=34) } & \multirow{2}{*}{$\mathrm{t}$} \\
\cline { 2 - 5 } & $\mathrm{M}$ & $\mathrm{SD}$ & $\mathrm{M}$ & $\mathrm{SD}$ & \\
\hline Ms & 49.93 & 5.18 & 38.19 & 5.05 & $-5.38^{* * *}$ \\
Mf & 23.54 & 3.23 & 31.08 & 6.36 & $6.92^{* * *}$ \\
Achievement motivation (Ms-Mf) & 20.39 & 6.99 & 7.12 & 8.63 & $-2.00^{* * *}$ \\
\hline
\end{tabular}

$* \mathrm{p}<0.05 \quad * * \mathrm{p}<0.01 \quad * * * \mathrm{p}<0.001$

Table 2. Paired-samples t test of achievement motivation between pre- and post-test in CL group

\begin{tabular}{cccccc}
\hline \multirow{2}{*}{ Achievement motivation } & \multicolumn{2}{c}{ Pre-test } & \multicolumn{2}{c}{ Post-test } & \multirow{2}{*}{$\mathrm{t}$} \\
\cline { 2 - 5 } & $\mathrm{M}$ & $\mathrm{SD}$ & $\mathrm{M}$ & $\mathrm{SD}$ & \\
\hline Ms & 49.93 & 5.18 & 38.29 & 6.38 & $-3.47^{*}$ \\
Mf & 23.54 & 3.23 & 31.39 & 7.48 & $6.50^{* *}$ \\
Achievement motivation (Ms-Mf) & 20.39 & 6.99 & 6.90 & 9.76 & $-2.15^{* *}$ \\
\hline
\end{tabular}

$* \mathrm{p}<0.05 \quad * * \mathrm{p}<0.01 \quad * * * \mathrm{p}<0.001$

Based on the result of Table 1, Difference was between the traditional teaching and the cooperative learning $(\mathrm{t}=-2.00, \mathrm{p}=0.000<0.001)$. The mean scores of motivation in the control group $(\mathrm{M}=7.12, \mathrm{SD}=8.63)$ was significantly lower than the experimental group $(\mathrm{M}=20.39, \mathrm{SD}=6.99)$.

From the result of Table 2, CL group had significant difference of pre and post test $(t=-2.15, p=0.000<0.001)$. The scores of pre-test $(\mathrm{M}=20.39, \mathrm{SD}=6.99)$ is lowerer than that of post test $(\mathrm{M}=6.90, \mathrm{SD}=9.76)$.

\section{Discussion}

Comparison of the cooperative form of teaching and the traditional teaching method revealed clear differences in the achievement motivation, and the result after the CL method implementing showed a significant difference between pre-and post test. All these indicated that the CL method can improve students' achievement motivation. The reason might be as fallows:

1) Higher self-efficacy can increase motivation

Weiner's (2000) attribution theory assumes that motivation is affected by how people attribute their past success or failure (i.e.; stable , constant, and thus uncontrollable factors versus unstable, temporary, and thus controllable factors). Bandura's (1993) self-efficacy theory maintains that, if individuals deem competence as "acquired" (i.e., controllable based on the attribution theory), they focus on personal improvement and maintain strong commitment to goals. Conversely when individuals deem competence as "inherent" (i.e., uncontrollable), they maintain a self-diagnostic focus and recoil from challenging tasks in fear of having to acknowledge low inherent ability in case of unsatisfying performance. Similarly, Covington's (1992) self-worth theory assumes that learners with low confidence often avoid working hard so that they can attribute failure to level of effort exert (controllable) to retain their sense of control and self worth.

2) More successful experiences can increase motivation

Based on the motivation theories, it appears that in order to enhance motivation, instruction needs to be tailored to help learners perceive competence as acquired skills and to enhance their sense of control over learning tasks. In order for learners to perceive competence as attainable through efforts and to make them believe their power in making a difference, allowing students to make improvement against their own past performance rather than against their classmates seems a reasonable solution. In cooperative learning, this pedagogical practice is called "equal opportunities for success" (Slavin, 1983), a feature shared by many cooperative learning methods. 
3) Setting a group goal can increase motivation

Locke and Latham's (1990) goal setting theory argued that human behaviors are regulated by goals and that the setting of personal goals are in turn influenced by factors such as group goals, role modeling, encouragement, and feedback. These factors are compatible with Slavin's (1995) model of cooperative learning, the setting of group goals will trigger motivation to learn, motivation to encourage group members to learn, and motivation to help group members to learn. students' achievement motivation is often higher in small-group activities because students feel more positive about being able to complete a task with others than by working individually (Johnson et al. 1991).

4) A positive relationships with classmates can increase motivation

When learning in a cooperative group setting, students develop a positive interdependence towards their classmates, which increases motivation (Kraus et al; 2009). In a cooperative learning setting, behaviors such as working hard, attending class, participating regularly, acknowledging others' efforts and receiving help from colleagues are encouraged. In other words, cooperative learning encourages positive peer pressure and learning becomes a valued activity. When success is based on the group's efforts rather than individual work, students attribute success to hard work rather than luck, so they are motivated to give their best.

\section{References}

Allen, W. H., \& Van Sickle, R. L. (1984). Learning teams and low achievers. Social Education, 48, 60-64.

Antil, L. R., Jenkins, J. R., Wayne, S. K., \& Vadasy, P. F. (1998). Cooperative Learning: Prevalence, conceptualizations, and the relation between research and practice. American Educational Research Journal, 35, 419-454.

Arends, R. I., \& Kilcher, A. (2010). Teaching for student learning: becoming an accomplished teacher. New York: Published in the Francis e- Library.

Atkinson, J., \& Feather, N. (1996). A Theory of Achievement Motivation. New York: Wiley and Sons.

Bandura, A. (1993). Perceived self-efficacy in cognitive development and functioning. Educational Psychologist, 28, 117-148. http://dx.doi.org/10.1207/s15326985ep2802_3

Bar-Tal, D., Frieze, I., \& Greenberg, M. (1974). Attributional analysis of achievement motivation, some applications to education. Chicago, IL: American Education Research Assocation Annual Meeting. (ERIC Document Peporduction Service Number ED 087 976)

Borich, G. D. (2007). Effective teaching methods "research -based practice." Ohio: Pearson Education Inc.

Chen, X. D. (2012). The Effect of Cooperative Learning on achievement Motivation of College Students. China Journal of Health Psychology, 20(3).

Cohen, E. G. (1994). Restructuring in the classroom: Conditions for Productive small groups. Review of Educational Research, 64, 1-35.

Cohen, R. J., \& Swedlik, M. E. (2005). Psychological testing and assessment "An introduction to tests and measurement" (6th ed.). New York: McGraw Hill Published.

Colquitt, J. A., \& Simmering, M. J. (1998). Conscientiousness, goal orientation, and motivation to learn during the learning process: A longitudinal study. Journal of Applied Psychology, 83, 654-665. http://dx.doi.org/10.1037/0021-9010.83.4.654

Cothran, D., \& Ennis, C. (1998). Curricula of mutual worth: Comparisons of students' and teachers' curricular goals. Journal of teaching in Physical Education, 17, 307-326.

Covington, M. V. (1992) Making the grade: A self- worth perspective on motivation and school reform. Cambridge, United Kingdom: Cambridge University Press. http://dx.doi.org/10.1017/CBO9781139173582

David, W., Johnson, R., \& Johnson, T. (2009). An education psychology success story: social interdependence theory and cooperative learning. Education Researcher, 38, 365-379. http://dx.doi.org/10.3102/0013189X09339057

Dunn, S. E., \& Wilson, R. (1991). Cooperative Learning in the Physical Education classroom. Journal of Physical Education, Recreation \& Dance, 62(6), 22-28.

Dyson, B, Griffin, L. L., \& Hastie, P. (2004). Sport Education, Tactical Games, and Cooperative Learning: Theoretical and Pedagogical Considerations. Quest, 56, 226-240. http://dx.doi.org/10.1080/00336297.2004.10491823 
Dyson, B. (2001). Cooperative Learning in an elementary physical education program. Journal of Teaching in Physical Education.

Dyson, B., \& Grineski, S. (2001). Using cooperative learning structures in physical education. Journal of Physical Education, Recreation \& Dance, 72(2), 28-31.

Gough, P. B. (1987). The key to improving schools: an interview with William Glsaaer. Phi Delta Kappan, 68(9), 656-662.

Grineski, S. (1998). Children, games, and prosocial behavior: Insight and connections. Journal of Physical Education, Recreation \& Dance, 60(8), 20-25.

Hao, X. G. (2010). Under the New Curriculum Objectives of the Curriculum Reform College P.E. Rational Thinking. Sichuan Spotrs Science. No.1 Mar.

$\mathrm{Hu}, \mathrm{H}$. Q. (2004). Apply cooperative learning strategy in aerobics education and its effects on mental health of female college students. Dissertation of PhD Degree of Yangzhou University

Hui-Chuan Liao. (2006). Effects of Cooperative Learning on Motivation, Learning Strategy Utilization, and Grammar Achievement of English Language Learners in Taiwan. Dissertation of University of New Orleans.

Janko, E. (1989). Knowing is not thinking. Phi Delta Kappan, 70(7) 543-554.

Jiang, Q. (2007). Change the role of P.E. Teachers under the New Curriculums Standard. Journal of Neimenggu Physical education Science, 20(3), 121-125.

Johnson et al. (1991). Interaction in Cooperative Groups: The Theoretical Anatomy of Group Learning. Cambridge University Press.

Johnson, D. W., \& Johnson, R. T. (1989). Cooperation and competition: Theory and research. Edina, MN: Interaction Book.

Johnson, D. W., Johnson, R. T., \& Holubec, E. J. (1986). Circles of learning: Cooperation in the classroom. Edina, MN: Interaction Book Company.

Johnson, D. W., Johnson, R. T., \& Holubec, E. J. (1998). Cooperation in the classroom (7th ed.). Edina, MN: Interaction Book

Johnson, D. W., Maruyama, G., Johnson, R. T., Nelson, D., \& Skon, L. (1981). Effects of cooperative, competitive, and individualistic goal structures on achievement: A meta analysis. Psychological Bulletin, 89, 47-62. http://dx.doi.org/10.1037/0033-2909.89.1.47

Kagan, S. (1989). On Cooperative Learning: A conversation with Spencer Kagan. Educational Leadership, 47, 8-11.

Keefe, J., \& Jenkins, J. (1993). Eye on Education: Instruction and the learning environment. Larchmont, NY.

Kraus et al. (2009). The Effect of Cooperative Learning and Feedback on E-Learning in Statistics. Learning and Instruction, 158-170. http://dx.doi.org/10.1016/j.learninstruc.2008.03.003

Locke, E. A., \& Latham, G. P. (1990). A theory of goal setting and task performance. Englewood Cliffs, NJ: Prentice Hall.

Mathieu, J. E., Tannenbaum, S. I., \& Salas, E. (1992). Influences of individual and situational characteristics on measures of training effectiveness. Academy of Management Journal, 35, 828-847. http://dx.doi.org/10.2307/256317

Mosston, M., \& Ashworth, S. (1986). Teaching Physical Education (3rd ed.). Columbus, OH: Merrill.

Perreault, R. J. (1983). An experimental comparison of cooperative learning to noncooperative learning and their effects on cognitive achievement in junior high industrial arts laboratories. (Doctoral dissertation, University of Maryland, 1982). Dissertation Abstracts International, 43, 3830A.

Quinones, M. A. (1995). Pretraining context effects: Training assignment as feedback. Journal of Applied Psychology, 80, 226-238. http://dx.doi.org/10.1037/0021-9010.80.2.226

Sherman, L. W., \& Thomas, M. (1986). Mathematics achievement in cooperative goal-structured high school classrooms. Journal of Educational Research, 70(3), 169-172.

Slavin, R. E. (1983). When does cooperative learning increase achievement? Psychological Bulletin, 94, 429-445. http://dx.doi.org/10.1037/0033-2909.94.3.429 
Slavin, R. E. (1987). Developmental and motivational perspectives on cooperative learning: A reconciliation. Child Development, 58, 1161-1167. http://dx.doi.org/10.2307/1130612

Slavin, R. E. (1990). Cooperative learning: Theory, research, and practice. New Jersey: Prentice Hall.

Slavin, R. E. (1991). Student team learning: A practical guide to cooperative learning. Washington, D.C.: National Education Association.

Slavin, R. E. (1996). Research on cooperative learning and achievement: What we know, what we need to know. Contemporary Educational Psychology, 21, 43-69.

Slavin, R. E. (2005). Cooperative Learning "Theory, Research and Practice”. London: Allyn and Bacon.

Syahrir, S. P. (2011). Cooperative Learning on the Achivement motivation and Mathematical Skills of Junior High School Students. Australian Journal of Basic and Applied Science, 5(10), 980-989. http://dx.doi.org/10.1006/ceps.1996.0004

Wang et al. (2004). Comparsion of Chinese traditional PE teaching pattern with the movement education in America. Journal of Physical Education, 11(5), 114-115.

Weiner, B. (2000). Intrapersonal and interpersonal theories of motivation from an attributional perspective. Educational Psychology Review, 12, 1-14. http://dx.doi.org/10.1023/A:1009017532121

Yeo, L. S., \& Tan, K. (2012). Attributional Style and Self-Efficacy in Singaporean Adolescent. Austrailan Journal of Guidance Counselling, 22(1), 82-101. http://dx.doi.org/10.1017/jgc.2012.1

Yoder, L. (1993). Cooperative learning and dance education. Journal of Physical Education, Recreation \& Dance, 64(5), 47-51, 56.

Yu, X. H. (2004, May). Basic Thoughts in P.E. Teaching Reform under the New curriculum Standard. Journal of Beijing Sport University, 27(5). 